DE

DE GRUYTER

OPEN
Journal of Intercultural Management

Vol. 7, No. 4, December 2015, pp. 69-81

DOI 10.1515/joim-2015-0031

Piotr Masiukiewicz ${ }^{1}$

Institute of Value Management, Warsaw School of Economics

\title{
Cultural and Religious Factors Versus Success in Business
}

\begin{abstract}
Cultural and religious factors do have some connection with results achieved in business; it is particularly well visible on the financial market. The paper presented possibilities of researching connections between cultural and religious factors and success in business, based on selected measures. Analysis covers three areas: top managers' incomes, effectiveness measured by return on capital, risk appetite of financial institutions with international capital and international board of managers. Indicators of correlations and comparison of measures used for analysis confirm inter-relationships of cultural and religious factors and success in business.
\end{abstract}

Key words: cultural factors, foreign equity, risk, success in business

\section{Introduction}

When it comes to research on how cultural and religious factors impact doing business and achieving financial success, quantitative methods seem to be underrepresented. However, available literature indicates to some kind of connection between these two areas. Globalization facilitates dynamic development of mixed ownership corporations that hire employees of various origins. It also allows rapid innovation and know-how sharing as well as exchange of experiences between international managerial staff; that in turn is not without impact on profits and market success of the company.

From the top-managers' point of view the success of their company is their personal success. Hence, could the cultural-religious background of chairmen and board members be linked with their success? Is the international management board more effective? Is it more successful? How does the national willingness to take risks influence financial performance and crisis resilience? 
The aim of this paper is to demonstrate that connections between culturalreligious factors and success in business can be researched by means of selected measures.

Success in business can be understood - in narrow sense - as the income of top managerial staff or companies' owners, or - in wider perspective - as company's effectiveness and high level of its financial indicators - which translate into individual success of top managers.

Research methods used in this paper include analysis of domestic and international literature, desk research and comparative analysis of chosen indexes.

\section{Success measures in business}

Correct selection of the enterprise success evaluation criteria is a debatable problem and certain limitations in research and statistical data availability sometimes hinder the application of the assorted set of these criteria. Linking the cultural factors with economic performance of the enterprise can be very difficult. ${ }^{2}$

As P. Drucker points out in his papers, quite commonly the main long-term goal of the enterprise is to survive on the market. In the situation of crisis some companies would take up a fight at all cost, including the fight for state aid (bailout). G.J Stigler, considered the pioneer of regulatory economics, devoted some attention to this issue. He formulated a thesis, that in research one should apply the survivor principle; defining the group of enterprises that are the most successful on the market in longer perspective. ${ }^{3}$ Acording to R. R. Gesteland there are two rules of thumb in international business, i.e.:

$1 /$ it is expected from the supplier of services to comply with the client and from the seller to comply with the buyer,

$2 /$ it is expected from the newcomer to obey local customs. ${ }^{4}$

Analyses published in Harvard Business Review indicate to the role of the foreign activity of the companies (including export) as a success factor. ${ }^{5}$

The author specifies these criteria of company's success: return on equity and assets, income level of the board members or the entrepreneur, the level of debt, the level of innovation, strategic approach to business and foreign activity, crisis resilience, risk level (capital adequacy ratio in credit institutions), market confidence index. ${ }^{6}$

\footnotetext{
1 Hens T., Wang M. Does Finance Have a Cultural Dimension? National Centre of Competence in Research Financial Valuation and Risk Management, Working Paper, no 377/2007

3 Jasiński L. J. Nobel z ekonomii, Wydawnictwo Key Text, Warszawa, 2008, p. 94

4 Gesteland R. R. Różnice kulturowe a zachowania w biznesie, PWN, Warszawa, 2000, p. 16

5 Stangierski P., Przybylik M., Sieczek M., Kamyk K. Niski poziom internacjonalizacji polskich firm, Harvard Business Review Pl, grudzień 2013 - styczeń 2014

6 Dec P. Masiukiewicz P. Measures of Success in Small and Medium-Sized Business in Poland, Kwartalnik Nauk o Przedsiębiorstwie, no 1/2014
} 
Whereas the quantitative measures of cultural diversity of the enterprise may include: foreign capital participation, foreign representation on the company's management board, national risk appetite indicators IDV [individualism index] and UAI [uncertainty avoidance index], percentage of international clients, number of foreign outposts etc. The IDV index represents the level of individualism (versus collectivism) in action; the highest index applies to countries (nationalities) with the highest level of individualism. The UAI index defines levels of uncertainty avoidance; the lower the index, the lower the avoidance. Both indexes were developed by G. Hofstede.

A broad issue of companies' crisis resilience requires a research model and surveys conducted within companies, that actually survived a crisis situation - that would enable researches to define the connection between the crisis resilience and the cultural and religious factors. ${ }^{8}$

\section{Religion and success in business}

The theory of religion influencing the ethics of doing business and the success in business has both its supporters and critics.

According to a classic theory of M.Weber it's the evangelical church members, who are most predestined to develop business and achieve financial success. However in the $20^{\text {th }}$ century the success on Wall Street belonged to Jewish businessmen and in the 80 s and 90 s to Asian tigers - countries with prevailing Hinduism. But that period was also a time of dynamic development of new economies and finances namely Islamic finances. Unconventional Islamic banking became a stable element of global economy and the assets belonging to these institutions exceeded $\$ 2$ trillion. ${ }^{9}$

7 Kurkliński L. Znaczenie kultury narodowej w zarządzaniu ryzykiem kredytowym w polskim systemie bankowym, w: Zarządzanie ryzykiem - reakcje i wyzwania pokryzysowe, red. L. Kurkliński, Wydawnictwo BIK, Warszawa, 2011, p. 77

8 Huczek M. Organizational culture and culture crisis, Zeszyty Naukowe Wyższej Szkoły Humanitas. Zarządzanie, no 2/2014 and Masiukiewicz P. Resistance of Islamic Banking to Crises, in: Considerations about the Economy, ed. D. Niedziółka, Warsaw School of Economics Press, Warsaw, 2015

9 Górak-Sosnowska K., Masiukiewicz P., Bankowość muzułmańska, Oficyna Wydawnicza SGH, Warszawa, 2013 and Masiukiewicz P. Development of Islamic Banking. Multicultural Aspects, Journal of Intercultural Management, no 6(3)/2014 


\section{Graph 1. Success in business based on achieved income and religious beliefs}

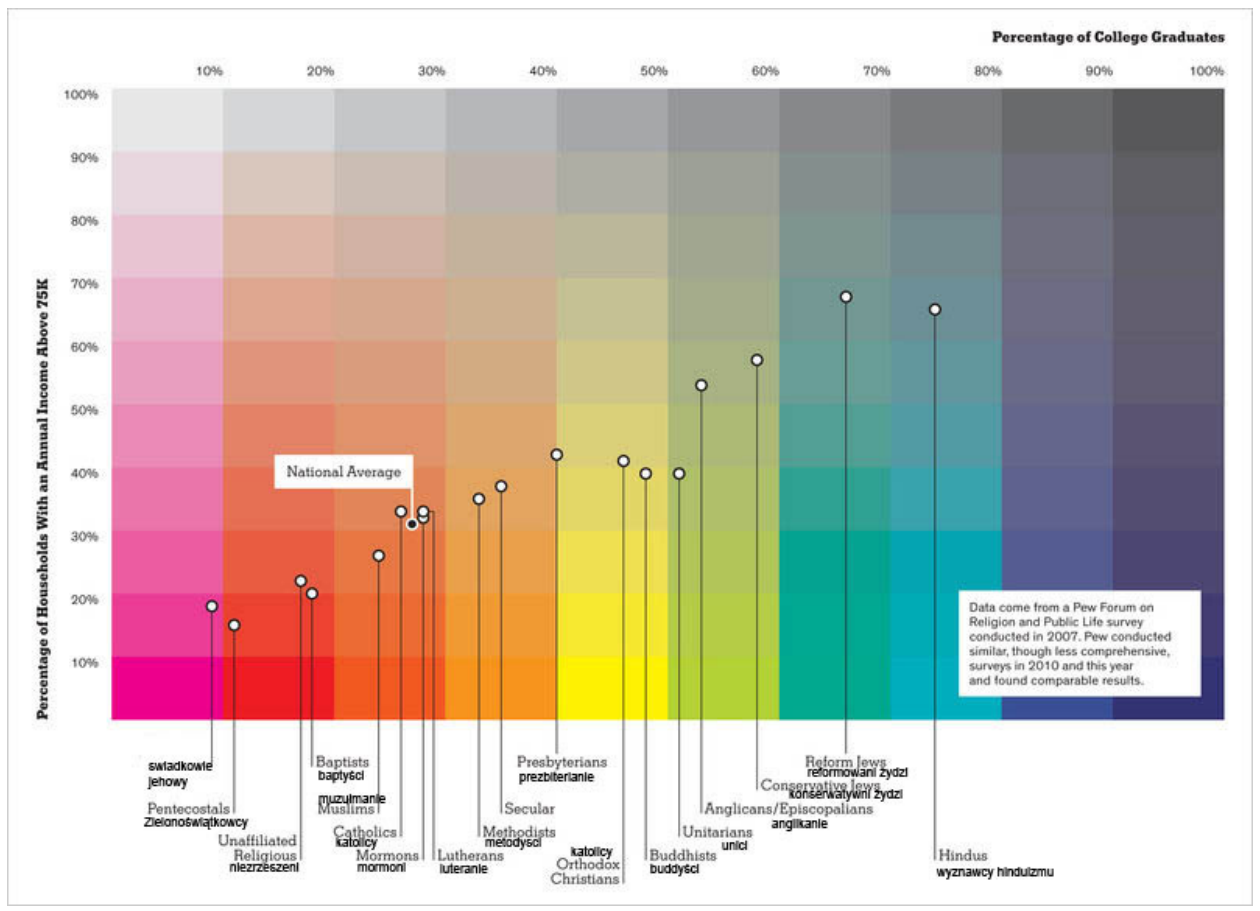

Source: Leonhardt D. Is Your Religion Your Financial Destiny? www.nytimes.com/2011/ is-your-religion-your-financial-destiny.html, access 10.12.2013

Unique survey carried out for The New York Times revealed that in 2011 the most successful in business were Reform Judaism followers and Hindus. ${ }^{10}$

The most affluent of major religions - including secularism — is Reform Judaism. Sixty-seven percent of Reform Jewish households made more than $\$ 75,000$ a year at the time the Pew Forum on Religion and Public Life collected the data, compared with only 31 percent of the population as a whole. Hindus were second, at 65 percent, and Conservative Jews were third, at 57 percent (graph 1).

On the other end are Pentecostals, Jehovah's Witnesses and Baptists. In each case, 20 percent or fewer of followers made at least $\$ 75,000$. Remarkably, the share of Baptist households making $\$ 40,000$ or less is roughly the same as the share of Reform Jews making $\$ 100,000$ or more. Overall, Protestants, who together are the country's largest religious group, are poorer than average and poorer than Catholics. That stands in contrast to the long history, made famous by Max Weber, of Protestant nations generally being richer than Catholic nations. $\square$

10 Leonhardt D. Is Your Religion Your Financial Destiny? www.nytimes.com/2011/is-yourreligion-your-financial-destiny.html, access 10.12.2013 
Many factors are behind the discrepancies among religions, but one stands out. The relationship between education and income is so strong that you can almost draw a line through the points on the graph no 1 . Social science rarely produces results this clean.

\section{Internationalisation and success in banks}

\subsection{Activity duration}

Polish financial market makes a good model for observation of how international business entities function on the market. More than 2/3 of banking sector belongs to foreign capital. Foreign capital appeared in banks after 1990 (after the economic reform introduced by $\mathrm{L}$. Balcerowicz) through privatization processes and purchasing of bankrupting Polish banks.

In the whole activity period on Polish market none of the foreign banks went for bankruptcy, while a range of Polish banks have been bankrupt. (table 1). During the international subprime mortgage crisis banks operating in Poland were crisis resilient; some of the foreign banks were even providing liquidity support to their owner banks. Therefore one can assume high survival rate of foreign banks on Polish market.

Surviving of a financial institution on the market depends on consumers' confidence.

Table. 1. Banks bankruptcy in Poland in the years 1990-2014

\begin{tabular}{|l|l|l|l|}
\hline \multirow{2}{*}{ No. } & Type of bank based on equity origin & \multicolumn{2}{|l|}{ Duration/numer of bankruptcies } \\
\cline { 3 - 4 } & & $1990-2001$ & $2002-2014$ \\
\hline 1 & Commercial banks with Polish capital & 6 & 0 \\
2 & Cooperative banks with Polish capital & 132 & 0 \\
3 & Commercial banks with foreign capital & 0 & 0 \\
\hline
\end{tabular}

Source: author's own source based on: Masiukiewicz P. Zarzqdzanie sanacja banku, Oficyna Wydawnicza SGH, Warszawa, 2011, p. 115

Building mutual trust within international teams can be particularly difficult; research shows that there are significant gaps between individual countries. According to S.C Schneider and J.L. Barsoux the statement that "most people can be trusted" was considered true by $70 \%$ respondents from Scandinavia, 50 $\%$ respondents from China, USA and Canada and only 20\% respondents from Romania, Turkey and Brazil. ${ }^{11}$

For many years consumer trust index on Polish banking market has been fairly high (over $70 \%$ ). Clients place their confidence in both Polish banks and banks with foreign capital.

11 Schneider S.C., Barsoux J.L., Managing Across Cultures, Prentice Hall, Harlow 2003, p. 15 


\subsection{Top managers' remunerations}

Members of management boards in foreign banks have been financially successful, their remunerations were highest in Poland. In 2012 surveys on remunerations of 115 top managers from 15 banks (including banks with Polish capital) listed at the Warsaw Stock Exchange were conducted. The report analyzed remunerations of 86 members of management boards, who worked all through the year 2012. ${ }^{12}$

In 2012 remunerations of banks' top managers were comparable to the remunerations in the previous year. In 2012 the median of remunerations of all managers amounted to PLN $1.58 \mathrm{~m}$. Persons who were members of management board all through the year 2012 were getting PLN $1.68 \mathrm{~m}$ (table 2).

Table 2. Remunerations of management boards members in banks in Poland in 2012

\begin{tabular}{|l|l|l|l|l|}
\hline $\begin{array}{l}\text { Specification (in thousands of } \\
\text { PLN) }\end{array}$ & $\begin{array}{l}\text { Managers' } \\
\text { numer }\end{array}$ & Lower quartile & Median & Upper quartile \\
\hline $\begin{array}{l}\text { 1. Total number of surveyed } \\
\text { managers }\end{array}$ & 115 & 962.0 & 1579.9 & 1992.8 \\
$\begin{array}{l}\text { 2. Number of surveyed } \\
\text { managers who worked all } \\
\text { through the year 2012 }\end{array}$ & 86 & 1178.0 & 1676.5 & 2162.0 \\
\hline
\end{tabular}

Source: author's own source based on: Wynagrodzenia cz̧onków zarz̨adów banków notowanych na GPW w 2012 roku", Raport, Sedlak \& Sedlak, Warszawa, 2014

Among top managers in banks staff turnover was high. Among 115 surveyed subjects, who served on management boards in the year 2012 more $25 \%$ did not work throughout the year (table 3).

Among managers serving on the board throughout the year 2012 the highest remuneration was paid to presidents of management boards. The median of their annual salary amounted for PLN $2.55 \mathrm{~m}$. The median of vice presidents' remuneration came up to PLN $1.43 \mathrm{~m}$ while salaries of board members came up to PLN 1,6 $\mathrm{m}$ (6\% decrease). There are some gaps in remunerations of Polish and foreign board members.

12 Wynagrodzenia członkón zarzquów banków notowanych na GPW w 2012 roku, Raport, Sedlak \& Sedlak, Warszawa, 2014 
Table 3. Selected positions in the salary rating of boards of managers' members in banks in Poland in 2012

\begin{tabular}{|c|c|c|c|c|c|}
\hline $\begin{array}{l}\text { No. in } \\
\text { ran- } \\
\text { king }\end{array}$ & $\begin{array}{l}\text { Name of member of } \\
\text { management board }\end{array}$ & Name of bank & Function & $\begin{array}{l}\text { Worked for } \\
\text { the whole } \\
\text { year or not }\end{array}$ & $\begin{array}{l}\text { Salary/year } \\
\text { PLN }\end{array}$ \\
\hline 1 & $\begin{array}{l}\text { Misbah Ur-Rahman- } \\
\text { Shah }\end{array}$ & $\begin{array}{l}\text { Bank Handlowy } \\
\text { (own USA) }\end{array}$ & Vicepresident & Yes & 5866000 \\
\hline 2 & Wiesław Thor & $\begin{array}{l}\text { BRE Bank } \\
\text { (own Germany) }\end{array}$ & Vicepresident & Yes & 4622201 \\
\hline 100 & $\begin{array}{l}\text { Przemysław Lech } \\
\text { Figarski }\end{array}$ & $\begin{array}{l}\text { Bank Ochrony } \\
\text { Środowiska (own } \\
\text { Poland) }\end{array}$ & Vicepresident & Not & 789000 \\
\hline 101 & Bohdan Tillack & $\begin{array}{l}\text { Nordea Bank } \\
\text { Polska (own } \\
\text { Sweden) }\end{array}$ & Vicepresident & Yes & 712800 \\
\hline 102 & Grzegorz Słoka & $\begin{array}{l}\text { Getin Noble Bank } \\
\text { (own Poland) }\end{array}$ & $\begin{array}{l}\text { Member of } \\
\text { manag. board }\end{array}$ & Not & 689000 \\
\hline
\end{tabular}

Source: author's own source based on: Wynagrodzenia członków zarzqadów banków notowanych na GPW w 2012 roku, Raport, Sedlak \& Sedlak, Warszawa, 2014

\subsection{Internationalization of the boards and the capital return}

Intercultural knowledge management (knowledge on cultural differences), which impacts international activity of enterprises and its usefulness for individual enterprises depend on their internationalization level. ${ }^{13}$ Intercultural knowledge is obviously of key meaning and it's indispensable within global companies and international consortiums, including exporters. ${ }^{14}$ However in case of local firms cooperating with foreign partners it's meaning is not so crucial. The subject of relations between culture and knowledge management processes appears in literature $^{6}$, but this approach does not concern (among others) the concept of intercultural knowledge management. ${ }^{15}$ Internationalization of the board of managers in the company helps to solve this problem.

Table 4. Banks with international management boards in Poland and their ROE index in the year 2014

\begin{tabular}{|l|l|l|l|l|}
\hline Lp. & Bank's name & $\begin{array}{l}\text { The number of } \\
\text { management board } \\
\text { members }\end{array}$ & $\begin{array}{l}\text { Foreign } \\
\text { management board } \\
\text { members }- \text { in \% }\end{array}$ & ROE index \\
\hline
\end{tabular}

13 Cieślik A., Multinational Enterprises, Foreign Knowledge and Host Country Wages, Equilibrium. Quarterly Journal of Economics and Economic Policy, vol. 7, issue 1/2012

14 Miroński J. Zarządzanie wiedzą międzykulturową, E-mentor no 3/2010

15 Chaney L.H., Martin J. S., International Business Communication, Pearson Prentice Hall, Upper Sadle River, New Jersey 2007. 


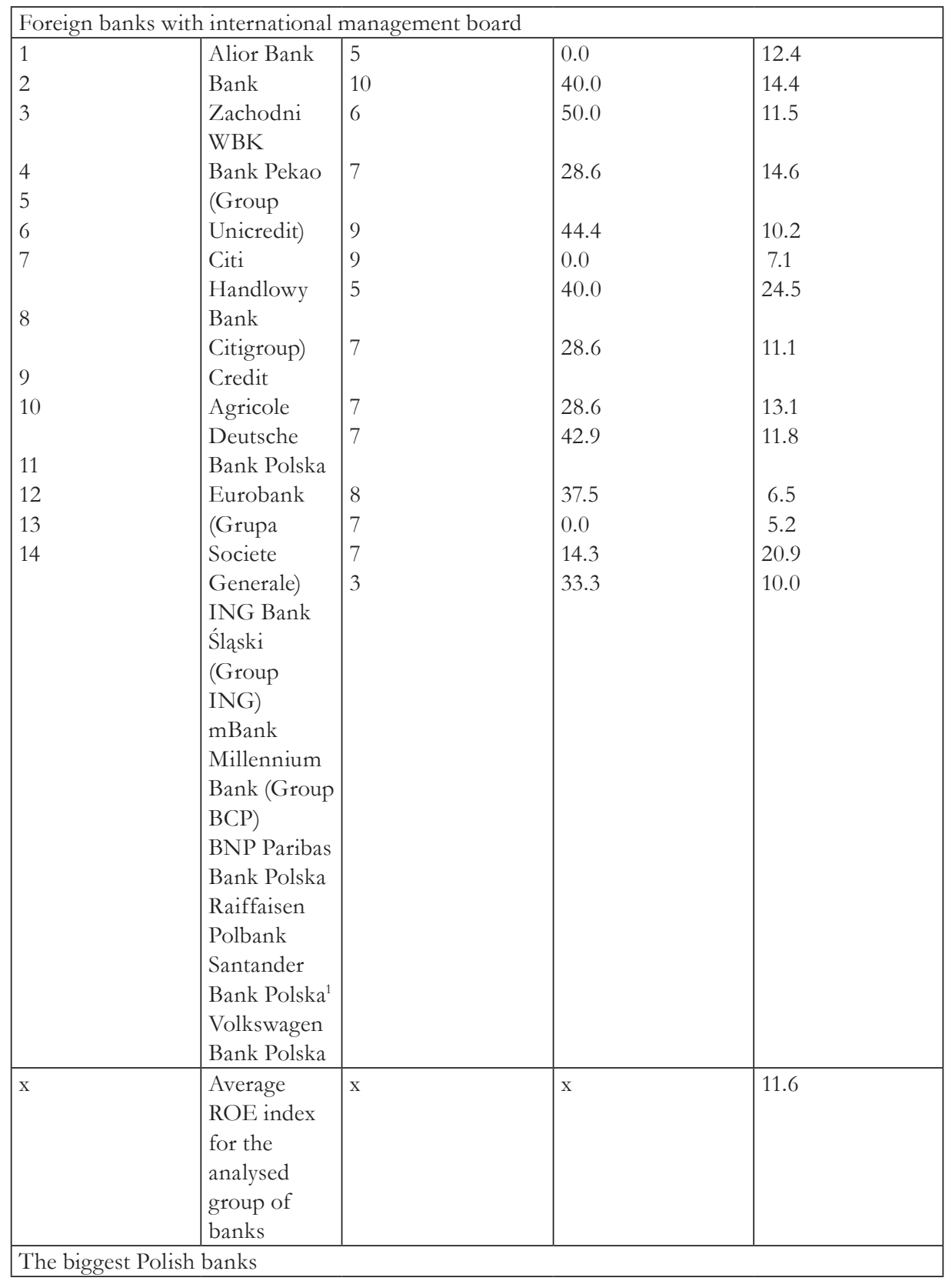




\begin{tabular}{|c|c|c|c|c|}
\hline $\begin{array}{l}1 \\
2 \\
3 \\
4\end{array}$ & \begin{tabular}{|l} 
PKO Bank \\
Polski \\
Bank \\
Ochrony \\
Środowiska \\
Getin Noble \\
Bank \\
Bank \\
Pocztowy \\
\end{tabular} & $\begin{array}{l}7 \\
5 \\
7 \\
4\end{array}$ & $\begin{array}{l}0 \\
0 \\
0 \\
0\end{array}$ & \begin{tabular}{|c|}
12.4 \\
4.5 \\
7.1 \\
10,5
\end{tabular} \\
\hline $\mathrm{x}$ & $\begin{array}{l}\text { Average } \\
\text { ROE for } \\
\text { analyzed } \\
\text { banks } \\
\end{array}$ & $\mathrm{x}$ & $\mathrm{x}$ & 8,6 \\
\hline $\mathrm{x}$ & $\begin{array}{l}\text { Correlation } \\
\text { index of } \\
\text { Pearson } \\
\text { (ROE and } \\
\text { foreign } \\
\text { management } \\
\text { board } \\
\text { members - } \\
\text { in } \% \text { ) }\end{array}$ & $\mathrm{x}$ & $\mathrm{x}$ & 0,357479 \\
\hline
\end{tabular}

Notes: ${ }^{1}$ Data for 2013.

Source: author's own source based on banks' information contained in annual reports and Krześniak-Sajewicz M. Banki odbija sobie niskie stopy podwył̇kami opłat, Rzeczpospolita, 16.04.2015

Proper managing of intercultural knowledge within a company helps - besides using the effects of intercultural diversity - to minimize potentially negative effects of these differences. For instance about $20 \%$ of managers working outside their own countries go through a deep culture shock, and - what's even worse - get frustrated because of difficulties in understanding both verbal and non-verbal communication between members of local culture, their customs and values. ${ }^{16}$

A synthetic measure of the company's success is a return on equity index (ROE) and its comparison in the peer group. ROE index was slightly higher in the group of researched banks with foreign capital than in Polish banks. Researched foreign banks (except for three) had international boards of managers.

Coefficient of correlation of foreign board members percentage and the ROE index level points to a low correlation of both coefficients, while absolute average ROE in banks with foreign member boards was much higher: it amounted to 11.6 $\%$ (Table 4).

16 Trompenaars F., Hampden-Turner Ch., Zarządzanie personelem w organizacjach zróżnicowanych kulturowo, Oficyna Ekonomiczna, Kraków 2005, p. 257 


\subsection{Risk level in banking industry and nationality}

Hens and Wang have formulated four main factors that shape managers' approach towards risk; i.e. the way of choosing a reference point, attitude towards risk in the context of loses and gains, risk aversion level and the method of estimating risk probability. ${ }^{17}$

National willingness to take risks indexes (by Hofstede) put under comparative analysis with such measures as: percentage of substandard loans in a given bank, size of reserves for the lost loans or capital adequacy ratio (CAR) help to define interdependence of these categories.

Comparison of IDV and UAI indexes as well as CAR for local banks and those with foreign capital (including ones with partially foreign boards - Table 4) shows significant interdependence of willingness to take risks and CAR level in multicultural banks (Table 5).

Average CAR for banks with foreign capital was higher than for Polish banks; it amounted to $14.3 \%$. Correlation coefficients on the level of 0,30762 for IDV and 0.40896 for UAI (reverse dependence) show a rather average strength relation between national risk indexes and the achieved capital adequacy ratios in banks in individual countries.

Similar research conducted by L. Kurkliński in 2010 has shown a low correlation of IDV with the percentage of lost loans in the group of 10 biggest banks with foreign and Polish capital in Poland. ${ }^{18}$

Table 5. Capital adequacy ratios and willingness to take risks by the country of origin of capital

\begin{tabular}{|l|l|l|l|l|}
\hline No. & Bank's name & Index IDV & Index UAI & $\begin{array}{l}\text { Capital adequacy } \\
\text { ratio }\end{array}$ \\
\hline \multicolumn{2}{|l}{ Banks with foreign capital }
\end{tabular}

17 Hens T., Wang M. Does Finance Have a Cultural Dimension? National Centre of Competence in Research Financial Valuation and Risk Management, Working Paper, no

18 Kurkliński L. Znaczenie kultury narodowej w zarządzaniu ryzykiem kredytowym w polskim systemie bankowym, in: Zarządzanie ryzykiem - reakcje i wyzwania pokryzysowe, ed. L. Kurkliński, Wydawnictwo BIK, Warszawa, 2011 


\begin{tabular}{|c|c|c|c|c|}
\hline \begin{tabular}{|l}
1 \\
2 \\
3 \\
4 \\
5 \\
6 \\
7 \\
8 \\
9 \\
10 \\
11 \\
\\
12 \\
13 \\
14
\end{tabular} & $\begin{array}{l}\text { Alior Bank (Italy) } \\
\text { Bank Zachodni WBK } \\
\text { (Spain) } \\
\text { Bank Pekao (Italy) } \\
\text { Citi handlowy Bank (USA) } \\
\text { Credit Agricole (France) } \\
\text { Deutsche Bank Polska } \\
\text { (Germany) } \\
\text { Eurobank (France) } \\
\text { ING Bank Śląski } \\
\text { (Netherlans) } \\
\text { mBank (Germany) } \\
\text { Millennium Bank (Portugal) } \\
\text { BNP Paribas Bank Polska } \\
\text { (France) } \\
\text { Raiffaisen Polbank (Austria) } \\
\text { Santander Bank Polska } \\
\text { (Spain) } \\
\text { Volkswagen Bank Polska } \\
\text { (Germany) } \\
\end{array}$ & $\begin{array}{l}76 \\
51 \\
76 \\
91 \\
71 \\
67 \\
71 \\
80 \\
67 \\
27 \\
\\
71 \\
55 \\
51 \\
67\end{array}$ & $\begin{array}{l}75 \\
86 \\
75 \\
46 \\
86 \\
65 \\
86 \\
53 \\
65 \\
104 \\
86 \\
70 \\
86 \\
65\end{array}$ & $\begin{array}{l}12.8 \\
12.9 \\
17.3 \\
17.5 \\
13.7 \\
14.0 \\
14.2 \\
14.2 \\
14.7 \\
15.2 \\
12.9 \\
12.9 \\
14.4 \\
14.1\end{array}$ \\
\hline \multicolumn{5}{|c|}{ Banks with Polish capital } \\
\hline $\begin{array}{l}1 \\
2 \\
3 \\
4\end{array}$ & $\begin{array}{l}\text { PKO BP } \\
\text { Bank Ochrony Środowiska } \\
\text { Getin Noble Bank } \\
\text { Bank Pocztowy }\end{array}$ & $\begin{array}{l}60 \\
60 \\
60 \\
60 \\
\end{array}$ & $\begin{array}{l}93 \\
93 \\
93 \\
93\end{array}$ & \begin{tabular}{|l|}
12.9 \\
14.0 \\
13.1 \\
13,4 \\
\end{tabular} \\
\hline $\mathrm{x}$ & $\begin{array}{l}\text { Pearson correlation } \\
\text { coefficient with regard to } \\
\text { capital adequacy ratio }\end{array}$ & 0.30762 & (-) 0.40896 & $\mathrm{X}$ \\
\hline
\end{tabular}

Source: own study based on Krześniak-Sajewicz M. Banki odbija sobie niskie stopy podwyخ்ami opłat, Rzeczpospolita, 16.04.2015 oraz http://www.geert-hofstede.com, cyt. za: Kurkliński L. Znaczenie kultury narodowej w zarzqdzaniu ryzykiem kredytowym w polskim systemie bankowym, w: Zarządzanie ryzykiem - reakcje i wyzwania pokryzysowe, ed. L. Kurkliński, Wydawnictwo BIK, Warszawa, 2011

\section{Conclusion}

Cultural and religious factors have some connection with success achieved in business; it is particularly visible on the financial market. It can be researched by comparative analysis of financial indicators and correlation coefficients defining national features.

Broad access of foreign capital to financial institutions in Poland triggered dynamic development of the financial market and transferring of managerial knowledge and knowhow from developed countries. It also provided strong financial basis, which in turn resulted in good financial indicators, crisis resilience 
and positive results of European stress-tests in recent years. At the same time social trust indicators were high for both foreign and local banks in Poland. Top managers in foreign banks have also been financially successful - they have been the best paid group in Poland.

Analysis of current capital adequacy ratios in banks with foreign capital as well as national indicators of willingness to take risks showed medium level of correlation.

Conducting periodic research on cultural and religious factors' influence on economic results of companies and their success in doing business appears to be possible and reasonable; it would make a significant platform for the assessment of the effects of business internationalization and adapting to global market conditions.

\section{References}

Chaney L.H., Martin J. S., International Business Communication, Pearson Prentice Hall, Upper Sadle River, New Jersey, 2007

Cieślik A., Multinational Enterprises, Foreign Knowledge and Host Country Wages, Equilibrium. Quarterly Journal of Economics and Economic Policy, vol. 7, issue 1/2012

Dec P. Masiukiewicz P. Measures of Success in Small and Medium-Sized Business in Poland, Kwartalnik Nauk o Przedsiębiorstwie, no 1/2014

Długopolska - Mikonowicz A., Ota T. Efektywna wspótpraca w zespołach międzykulturowych, www.wsb.pl/sites/efektywna wspolpraca w zespolach miedzykulturowych, access 15.04.15

Gesteland R. R. Różnice kulturowe a zachowania w biz̨nesie, PWN, Warszawa, 2000

Gilles H., Hui K. Does Religion Matter in Corporate Decision Making in America? Journal of Financial Economics, no 93/2009

Górak-Sosnowska K., Masiukiewicz P., Bankowość muzutmańska, Oficyna Wydawnicza SGH, Warszawa, 2013

Hens T., Wang M. Does Finance Have a Cultural Dimension? National Centre of Competence in Research Financial Valuation and Risk Management, Working Paper, no 377/2007

Huczek M. Organizational culture and culture crisis, Zeszyty Naukowe Wyższej Szkoły Humanitas. Zarządzanie, no 2/2014

Jasiński L. J. Nobel zekonomii, Wydawnictwo Key Text, Warszawa, 2008

Krześniak-Sajewicz M. Banki odbija sobie niskie stopy podwyżkami opłat, Rzeczpospolita, 16.04.2015

Kurkliński L. Znaczenie kultury narodowej w zarzqdzaniu ryzykiem kredytowym w polskim systemie bankowym, in: Zarządzanie ryzykiem - reakcje i wyzwania pokryzysowe, (ed.) L. Kurkliński, Wydawnictwo BIK, Warszawa, 2011

Leonhardt D. Is Your Religion Your Financial Destiny? www.nytimes.com/2011/is-your-religion-your-financial-destiny.html, access 10.12.2013

Masiukiewicz P. Zarz̨qdzanie sanacja banku, Oficyna Wydawnicza SGH, Warszawa, 2011 
Masiukiewicz P. Development of Islamic Banking. Multicultural Aspects, Journal of Intercultural Management, no 2(3)/2014

Masiukiewicz P. Resistance of Islamic Banking to Crises, in: Considerations about the Economy, ed. D. Niedziółka, Warsaw School of Economics Press, Warsaw, 2015

Miroński J. Zarzadzanie wiedz̨a miedzykulturowa, E-mentor no 3/2010

Schneider S.C., Barsoux J.L., Managing Across Cultures, Prentice Hall, Harlow, 2003

Stangierski P., Przybylik M., Sieczek M., Kamyk K. Niski poziom internacjonalizacji polskich firm, Harvard Business Review Pl, grudzień 2013 - styczeń 2014

Trompenaars F., Hampden-Turner Ch., Zarzqdzanie personelem w organizacjach zróżnicowanych kulturowo, Oficyna Ekonomiczna, Kraków, 2005

Wynagrodzenia członków zarzqdów banków notowanych na GPW w 2012 roku, Raport, Sedlak \& Sedlak, Warszawa, 2014 